\title{
MAJOR RÓBERT
}

\section{A formális jogértelmezés veszélyei a közlekedés körében}

\begin{abstract}
A helyváltoztatási igény egyidős az élettel. Nem csupán a fejlett társadalmakban, de már az élet megjelenésétől megfigyelhető annak igénye, hogy az adott élőlény valamilyen céllal egyik helyről a másikra kerülhessen. A modern társadalomban ez a mozgás differenciálódott és nem csupán az igénylö, hanem az igényelt dolog mozgatását is jelenti. Ez a mozgás a helyváltoztatás. A közlekedés e helyváltoztatást jelenti, mely fogalmat definíciószerüen a következőképpen foglalhatjuk össze. A közlekedés ,személyeknek illetve tárgyaknak jármüvekkel való rendszeres szállítása, forgalma"'. E formai meghatározás mellett azonban érdemes felállítani egy tartalmi meghatározást is. A közlekedés személyeknek és dolgoknak olyan tömeges helyváltoztatása, amely sajátos technikai eszközök igénybevételével, részint a közlekedésben dolgozók termelőmunkája révén szabályszerúen és tervszerüen ismétlődve rendszeresen, részint nem termelő egyéni tevékenységként, de mindenképpen célhoz kötötten valósul meg. ${ }^{2}$ A modern korban a közlekedés tárgyaként megjelenő személyek, illetve áruk kiegészülnek a szellemi termékekkel, gondolatokkal, információkkal is. A modern társadalmak jogrendszerének része a közlekedés jogi szabályozása, ám e területen számos jogszabályi rendelkezéssel találkozhatunk, amelyek a klasszikus felosztás szerint a legkülönbözőbb jogágakhoz tartoznak. A közlekedési jogot így egy olyan funkcionális jogágnak tekinthetjük, amelyhez a hagyományos jogágakba egyébként beletartozó jogszabályok nem a megszokott csoportosítás, hanem funkciójuk, azaz a közlekedés szabályozása alapján sorolhatók. Ennek megfelelően közlekedési jognak nevezhetjük azon jogforrásoknak az összességét, amelyek a közúti, a vasúti, a vízi, valamint a légi közlekedést szabályozzák.

A valamennyi közlekedési ágazatra jellemző ember-jármü-környezet hármas felosztás mindegyik eleméhez kapcsolódó alapvető jelentőségű rendelkezéseket törvényi szintű szabályozás keretében rögzítették. A részletszabályokat pedig alacsonyabb szintü ágazati normák tartalmazzák. Olyan köz-
\end{abstract}

1 Magyar Értelmező Kéziszótár. Akadémiai Kiadó, Budapest, 1978

2 Major Róbert: Közlekedésrendészet. Egyetemi tankönyv. Nemzeti Közszolgálati Egyetem, Budapest, 2016, 19. o. 
lekedési jogi környezetet kell teremteni, amelyben a közlekedésben részt vevők könnyen, gyorsan és egyértelmüen elboldogulnak, míg a jogalkalmazók könnyen, gyorsan és egyértelmüen képesek ítélkezni. ${ }^{3}$ A közúti közlekedés tekintetében a leggyakrabban alkalmazott jogszabály a közlekedésben részt vevő személyek magatartását szabályozó 1/1975. KPM-BM együttes rendelet a közúti közlekedés szabályairól, amelyet hagyományosan csak KRESZként említünk.

A KRESZ értelmezése során is alapvető jelentősége a nyelvtani értelmezésnek van, azonban egyes esetekben érdemes a jogszabály értelmezésének más módszerét is átgondolni. Mielőtt azonban az értelmezési módszerekre térnénk, meg kell jegyezni a KRESZ értelmezésével kapcsolatban azt a jellegzetességet, hogy arra elsősorban a közlekedésben részt vevők mindennapi tevékenysége során kerül sor. A jogszabály jogalkalmazói értelmezése tehát a hétköznapi ember, a közlekedésben részt vevő ember mint a KRESZ tényleges alkalmazója oldalán jelenik meg. Ha az értelmezés téves, hibás, vagy pontatlan, akkor szabályszegésnek minősülhet az esemény, ami pedig szabálysértési eljárást, közigazgatási bírságot, esetleg büntetőjogi szankciót von maga után. Ezekben az eljárásokban már a hatóság oldalán megjelenő jogértelmezés kerül elötérbe. Alapvetés, hogy a közlekedésben részt vevők jogkövetésének erősítését az szolgálja, ha a hatóság értelmezése és a „laikus” közlekedő értelmezése között lényegi különbség nem mutatkozik. Praktikusan egy adott közlekedési szabály betartása, vagy megszegése egyértelmủ legyen. A KRESZ azonban nem csak kógens jellegü szabályokat tartalmaz, amelyek megítélése általában egyszerú, például $55 \mathrm{~km} / \mathrm{h}$ sebességgel való haladás az több, mint a megengedett $50 \mathrm{~km} / \mathrm{h}$ sebességgel való haladás. A számos diszpozitív jellegü szabály gyakran vet fel értelmezési kérdéseket. Az ilyen jellegű szabályok tipikus példája lehet a „kellő időben” alkalmazott irányjelzés, vagy a „mérsékelt sebesség” alkalmazása. E szabályok értelmezése mindennapi nehézséget okozhat, hiszen például a jármüvezető mérsékli a sebességét a kijelölt gyalogos-átkelőhely előtt, de a baleset mégis bekövetkezik, akkor a hatóság valószínűleg azt az álláspontot fogja képviselni, hogy a sebességmérséklés nem volt megfelelö mértékü, annak ellenére, hogy a járművezető a szabályt formálisan betartotta, hiszen lassabban haladt, mint korábban, tehát mérsékelte a sebességét.

3 Major Róbert: A közúti közlekedési balesetek megelőzése, különös tekintettel a rendőrség lehetőségeire és korlátaira. PhD-értekezés, Pécsi Tudományegyetem Állam- és Jogtudományi Kar, Pécs, 2010, 10. o. 
A jogértelmezésnek általában négy szintjét különböztetjük meg, úgymint a nyelvtani, a logikai, a rendszertani és a történeti értelmezés. ${ }^{4}$ Nyilvánvaló, hogy a felsorolt értelmezési módszerek az értelmezési tevékenység egymásra épülő szakaszait jelentik. Ha az adott módszer megnyugtató eredményre nem vezet, eggyel magasabb szintre kell lépni. Az 1990. évhez kötődő politikai-gazdasági rendszerváltozás után azonban újra fellelhető egy ötödik értelmezési szint, amely a szocialistának nevezett jogi korszakban ideológiai okokból háttérbe került. Ez az értelmezési szint a teleologikus jogértelmezés. ${ }^{5}$ A teleológia görög eredetü kifejezés, amely olyan idealista tanítást jelent, ,, amely szerint a természetben minden egy bizonyos elöre megszabott cél megvalósitására jött létre és minden jelenség ennek kiteljesedését szolgál$j a$ "'. Ez a módszer tulajdonképpen a jogalkotó jogalkotási tevékenységével elérendö cél feltárását jelenti.

A KRESZ rendelkezéseinek értelmezésekor különösen veszélyes lehet, ha a jogalkalmazó mereven ragaszkodik a leírt jogszabályi rendelkezések nyelvtani tartalmához, mert a megfelelő absztrakció hiányában téves következtetésekre juthat. A közúti közlekedés szabályai között szükségszerüen jelentős számban fordulnak elö diszpozitív jellegü normák, amelyek értelmezése eleve jogalkalmazói értékelést igényel. A formális jogértelmezés veszélye azonban a kógens jellegü normák esetében is fennáll. Nehéz feladat elé állítja a jogalkalmazót a nyelvtani értelmezés eredményeként adódó szabály, ha a jogszabályszöveget csupán ezen a szinten kell tartania. Egyszerü példával megvilágítva: a KRESZ 40. § (1) bekezdése értelmében megállni az úttest menetirány szerinti jobb szélén, azzal párhuzamosan szabad. A párhuzamos szó jelentésével mindenki tisztában van, azaz tudja, hogy ha a személygépkocsijának jobb első kereke a járdaszegélytől 10, míg a hátsó kereke $11 \mathrm{~cm}-$ re található, akkor az nem párhuzamos. Ha nem párhuzamos, akkor szabályszegő módon történt a megállás? A példán keresztül könnyen belátható, hogy a megfelelő értelmezési szintre emelve a párhuzamos szót, arra a következtésre juthatunk, hogy a jogalkotó szándéka nem a geometriai értelemben vett párhuzamosságra vonatkozik, hanem arra, hogy a jármű hossztengelye ne zárjon be túl

\footnotetext{
4 Például Lamm Vanda - Peschka Vilmos (szerk.): Jogi lexikon. KJK, Budapest, 1999; Bíró György Lenkovics Barnabás: Magyar polgári jog. Általános tanok. Novotni alapítvány, Miskolc, 1999; Visegrády Antal: Jogi alaptan. Pécs, 1996; Szilágyi Péter: Jogi alaptan. Osiris Kiadó, Budapest, 2001; Szigeti Péter: Jogtani és államtani alapvonalak, Rejtjel Kiadó, Budapest, 2002

5 Például Takács Albert: A jogértelmezés alapjai és korlátai. Jogtudományi Közlöny, 1993/3.; Lábady Tamás: A magyar magánjog (polgári jog) általános része. Dialóg Campus Kiadó, Budapest-Pécs, 1997; Szabó Miklós: Jogi alapfogalmak. Bíbor Kiadó, Miskolc, 2002

6 Bakos Ferenc: Idegen szavak és kifejezések szótára. Akadémiai Kiadó, Budapest, 1976
} 
nagy szöget az úttest szélének vonalával, ne lógjon ki a megállás vagy várakozás céljára - akár útburkolati jellel, akár csak képzeletben - kialakított térrészből. Ha a logikai értelmezési szintet tekintjük, akkor az is belátható, hogy a jogszabály rendelkezései között megtalálható párhuzamos, merőleges és ferde várakozási rendre utaló szabályok közül kerül sor az egyik kiemelésére, tehát levezethető, hogy a párhuzamosan kitétel arra vonatkozik, hogy a jármüveknek nem szabad merőlegesen, illetve ferdén elfoglalniuk a várakozóhelyet. Ebben a példában tehát a jármüvezető csak formálisan szegte meg a szabályt, azaz magatartása nem tekinthetö szabályszegönek.

Gyakorlati jelentőséggel nagyobb mértékben bíró problémát jelent az az eset, amikor lakott terület kezdetén a közút kezelöje úgy ítéli meg, hogy a bevezető szakaszon az $50 \mathrm{~km} / \mathrm{h}$ sebességnél nagyobb, általában 70, vagy 80 $\mathrm{km} / \mathrm{h}$ sebesség is megengedhető. Az erre utaló jelzőtáblát azonban nem a lakott terület kezdete táblával együtt - mert akkor az a teljes lakott területre volna hatályos ${ }^{7}-$, hanem azt követően, az észlelést lehetővé tevő távolságban helyezik el. A jogszabályi rendelkezés nyelvtani értelmezése szerint a lakott terület kezdete jelzőtábla és az az utána kihelyezett $50 \mathrm{~km} / \mathrm{h}$ sebességnél nagyobb sebességet engedélyező jelzőtábla közötti útszakaszon $50 \mathrm{~km} / \mathrm{h}$ lenne a megengedett sebesség. Ez a következtetés ellentétes a közútkezelő szándékával, így - bár formális jogértelmezés szerint helyes - a jogértelmezés megfelelő szintjét alkalmazva, téves. A jelzett szakaszon az emelt sebesség irányadó. Hasonló értelmezési nehézség alakul ki ezeken a helyszíneken az ellentétes irány tekintetében, azaz a lakott terület elhagyásakor. Az emelt sebességet lehetővé tevő jelzőtábla hatályát ugyanis csak és kizárólag a mozgó jármüvekre vonatkozó tilalmak vége vagy a sebességkorlátozás vége jelzötáblák, illetve a következő útkereszteződés kezdete szünteti meg ${ }^{8}$, azaz a lakott terület vége jelzőtábla e szerint a nyelvtani értelmezés szerint nem érinti a sebességkorlátozás hatályát. Formálisan - tehát helytelenül - értelmezve a szabályt arra a következtetésre juthatnánk, hogy egy más (kisebb vagy nagyobb) sebességértéket jelölő sebességkorlátozó jelzőtábla sem szünteti meg a tábla hatályát, s ez nyilvánvalóan hibás irány. A helyes értelmezés szerint minden olyan jelzőtábla, amely más maximális sebességértékre utal, megszünteti a sebességkorlátozás hatályát, pontosabban megváltoztatja azt. Így a

7 KRESZ 14. § (8) bekezdés. Meg kell azonban jegyezni, hogy ez a szabály ételmét vesztette a Korlátozott sebességü övezet intézményének 1995. évi bevezetésével, hiszen e jelzőtáblákkal bármilyen terület kijelölhető korlátozott sebességủ övezetnek, így a teljes lakott terület is.

8 KRESZ 14. § (6) bekezdés 
lakott terület kezdetét, végét, a lakó-pihenő övezetet és a korlátozott sebességü övezetet jelző táblák a sebességkorlátozás hatályát megszüntetik.

Hasonlóan formális jogértelmezés kényszerített már ki jogszabályi változást is, például a biztonsági öv használata tekintetében. A korábbi megfogalmazás szerint becsatolt biztonsági övvel lehetett csak közlekedni, mely rendelkezés formális értelmezésével jogkövetőnek tekintették azt a járművezetőt, aki a háta mögött, vagy az ülés háttámlája mögött elvezetett, ám becsatolt biztonsági övvel közlekedett. A szabályozás hatályos megfogalmazása szerint a személynek biztonsági öv becsatolásával kell magát rögzítenie ${ }^{9}$. Bármilyen precíz legyen is a jogalkotás, a formális jogértelmezés veszélye fennállhat, hiszen ezen átfogalmazott rendelkezés tekintetében is előfordulhat az a hibás következtetés, hogy a becsatolt, ám a vezető nyakán körbetekert biztonsági öv használatát jogkövetőnek minősítik. A hasonló jogszabályhelyek értelmezésekor mindig érdemes a „rendeltetésszerü”, „üzemszerü” vagy „szabályos” használatról említést tenni, akár tartalmazza ezt az utalást a jogszabály szövege, akár nem.

A formális jogértelmezés néha elképesztő következményekre vezethet, például amikor a személygépkocsit az úttesten toló személy magatartását tekintettel arra, hogy gyalogosként nem a számára meghatározott helyen és módon, hanem az úttesten közlekedik - jogellenesnek minősítjük, vagy hasonlóan járunk el a közút fenntartásában, tisztításában, a hulladékszállításban részt vevő személyekkel szemben. A formális szabályszegés nem szabályszegés. Nincs ez másként a formális szabálykövetés esetén sem. Például amikor a becsatolt motorkerékpár-bukósisakra vonatkozó szabályt tekintjük ${ }^{10}$, és a becsatolt szíjat a sisak viselője a sisak belsejébe hajtva illeszti a sisakot a fejére, magatartása formálisan elégíti ki csak a normát, így a rendeltetésszerüség hiánya miatt magatartása jogszabálysértő. A jármüvezetés személyi feltételei között található szabály, mely szerint a vezetői engedélyt a jármüvezetőnek vezetés közben „,magánál kell tartania”, szintén okozott gyakorlati problémát, amikor jogellenesnek minősítették annak a járművezetönek a magatartását, aki a vezetői engedélyét a jármű csomagterében elhelyezett táskában és nem „magánál” tartotta. Meggyőződésünk, hogy ezen, különleges - gyakran nem is a szük értelemben vett közlekedés körébe tartozó - esetek konkrét jogszabályi rendelkezésbe való emelése téves irány, hi-

9 KRESZ 48. § (4) bekezdés, amely többször, de lényegében 1997-ben változott. A korábbi megfogalmazás szerint , csak abban az esetben szabad közlekedni, ha a biztonsági övvel felszerelt ülésen utazó személy biztonsági öve be van csatolva”.

10 KRESZ 48. § (9) bekezdés: „, ... személynek becsatolt motorkerékpár-bukósisakot kell viselni”. 
szen mindig lesznek olyan rendkívüli helyzetek, amelyekre a jogalkotó szükségszerüen nem készülhet fel előre. Így a helyes eljárás a KRESZ rendelkezéseinek alapelvekkel összhangban történő értelmezése, és a formális jogértelmezés módszerének meghaladása.

Érdemes további néhány példát kiemelni, rávilágítva ezzel a formális jogértelmezés veszélyeire. Kijelölt gyalogos-átkelőhely előtt személygépkocsival öt, tehergépkocsival tizenöt méter távolságon belül tilos megállni. Előfordulhat az a helyzet, hogy egy tehergépkocsi jellegzetességeit megtestesítö, ám személygépkocsiként nyilvántartott jármü öt méteren kívül, de tizenöt méteren belül állva zavarja a gyalogos észlelhetőségét, helyzete mégis jogszerü. Ugyanakkor a mögötte, az átkelőtől kb. tíz méterre álló személygépkocsi jellegü, ám tehergépkocsiként nyilvántartott jármü formálisan szabályszegő módon áll. Szintén tilos megállni olyan helyen, ahol a jármü fényjelző készülék vagy jelzőtábla jelzésének észlelését akadályozza. A KRESZ rendszerében viszont a „sávozott terelötábla” nem a jelzőtáblák között szerepel, hanem az a 20. § rendelkezései szerint egyéb közúti jelzésnek minősül. Elvárható, hogy az ilyen jelzést takaró járművezető megállása ne minősüljön jogszerünek, hiszen a hivatkozott tábla csak a formális jogértelmezés szerint nem minősül jelzőtáblának.

A formális jogértelmezés határát jelentheti az Állj! Elsőbbségadás kötelezö jelzőtáblánál elvárt járművezetői magatartás megítélése. A jogszabályi rendelkezés nyilvánvaló és egyértelmü: a meghatározott helyen meg kell állni, és a kereszteződésbe való behaladás előtti meggyőződési kötelezettség csak a megállás után következik. Ugyanakkor, ha figyelemmel vagyunk arra a tényre is, hogy ezt a jelzőtáblát az út kezelője csak akkor helyezheti ki, ha az útkereszteződés beláthatósági viszonyai az elsőbbséggel bíró észlelését csak megállással teszik lehetővé, megállapíthatjuk, hogy belátható kereszteződésekben a megállás formális elmaradása (például csupán $1 \mathrm{~km} / \mathrm{h}$ sebességre való lassítás), de a meggyőződési kötelezettség maradéktalan teljesítése nem tekinthető szabályszegő magatartásnak. Nyilvánvaló azonban, hogy a megállás olyan jellegü elmulasztása, amely a meggyőződést nehezíti vagy veszélyezteti, jogellenes, és szankciót kell maga után vonnia. Téves és helytelen azonban az ilyen helyszíneken a megállási kötelezettséget formálisan nem teljesítőkkel szembeni rendészeti fellépés.

A leállósáv szabálytalan - a gyorsabb előrehaladást célzó - használatának terjedése a jogalkotót e területen is beavatkozásra késztette. A 2009. évi KRESZ-módosítás a szabályos leállósáv-használat érdekében tételesen rögzítette azokat a kivételes eseteket, amelyekben adott jármủ a leállósávon ha- 
ladhat, megállhat vagy várakozhat. A szabályozás, amelynek célja kétségtelenül helyes, felemás precízsége miatt téves következtetések levonására adhat alapot. Abból ugyanis, hogy az útfenntartást vagy úttisztítást végző jármü leállósávon való tartózkodása jogszabályi várakozási tilalom alóli kivételként van nevesítve, arra lehet következtetni, hogy a jogalkotó az ilyen jármüvek jelenlétét csak abban az esetben tekinti jogszerünek, ha az a jogszabályban ténylegesen nevesítve van. A KRESZ rendszerében más helyeken, például nyílt villamospályán, autóbusz-forgalmi sávban vagy kerékpársávban ilyen jármüvek e logika szerint nem haladhatnak, tehát e területeken a téli időszakban síkosságmentesítés, vagy más időszakokban felülettisztítás nem lenne végezhető. Ez a szabályozás is jó példája a jogalkotás valós problémára történő reagálásának túlzott mértékére, hiszen mind szabálysértési, mind büntetőeljárásban, de még a közigazgatási eljárásban is megvannak azok az általános jogintézmények, amelyek a formális szabályszegő magatartások esetén biztosítják az „elkövető” büntetlenül maradását. Így a valóságban előforduló különleges helyzetekre elsősorban nem jogalkotási, hanem jogalkalmazási eszközökkel, helyes jogértelmezéssel kell reagálni. 